\title{
Krónikus, nem bakteriális, multicentrikus osteomyelitis a mandibulában
}

\author{
Danka Eszter dr. ${ }^{1}$ - Pintér Gábor Tamás dr. ${ }^{2}$ \\ Keresztúri Márton ${ }^{3}$ - Szabó György dr. ${ }^{2}$ \\ Semmelweis Egyetem, Fogorvostudományi Kar, ${ }^{1}$ Konzerváló Fogászati Klinika, \\ ${ }^{2}$ Arc-, Állcsont-, Szájsebészeti és Fogászati Klinika, Budapest \\ ${ }^{3}$ Semmelweis Egyetem, Fogorvostudományi Kar, \\ fogorvostan-hallgató, Budapest
}

\begin{abstract}
A krónikus, nem bakteriális multicentrikus osteomyelitis ritka steril gyulladásos csontelváltozás, amely a legtöbbször a hosszú csöves csontokat érinti, de létrejöhet más csontokban is. A mandibulában az esetek 1,5-3\%-ában fordul elő. A maxillofacialis sebészeti irodalomban az elnevezéssel kapcsolatban nincs egységes álláspont, bizonyos fokú konfúzió észlelhető. A dolgozat célja bemutatni a betegséget és az ezzel kapcsolatos kutatásokat, információkat az arc-állcsont sebészetre koncentrálva. Két esetet retrospektíve tárgyalnak, mindkettőnek a mandibulájában többszörös elváltozás volt. Klinikailag, radiológiailag, hisztológiailag nem bakteriális eredetű idült, többgócú csontgyulladást lehetett megállapítani. A betegség mindkét esetben több évig tartott. A dolgozat egy 17 és egy 43 éves nő kapcsán tárgyalja a krónikus, nem bakteriális, multicentrikus recidiváló osteomyelitis diagnosztikus kritériumait: állcsontfájdalom és -duzzanat, radiológiailag többszöri gyulladásos elváltozás. A komputertomográfos vizsgálat az érintett mandibularész típusos expanzióját, a csontvelő sclerosisát, kis gócokban rosszul meghatározható felritkulásokat és a periosteum lamelláris reakcióját mutatta. Mindkét beteg esetében hosszú eredménytelen antibiotikus kezelés történt, a gyulladás többszöri fellángolásával. A megfelelő kezelés után, amely nonszteroid gyulladáscsökkentőkből, majd szteroidból állt, hosszú fájdalom- és gyulladásmentes időszak következett be. A krónikus, többgócú, nem bakteriális eredetű osteomyelitis ritkán fordul elő az állcsontokban, de valószínú, hogy korrekt diagnózis esetén az irodalomban leírtaknál gyakoribb lehet. A tipikus ismétlődő fájdalom és duzzanat, a hosszadalmas lefolyás a radiológiai ismérvekkel együtt megadja a kórismét, és a kezelésben elkerülhető lehet az eredménytelen antibiotikus terápia és a többszöri biopszia. A megfelelő gyógymód: a nonszteroid gyulladáscsökkentők vagy szteroidok, minimáldózisú fenntartó kezeléssel. Orv Hetil. 2018; 159(43): 1761-1766.
\end{abstract}

Kulcsszavak: krónikus osteomyelitis, mandibulaosteomyelitis, recidiváló csontgyulladás

\section{Chronic, nonbacterial, multicentric osteomyelitis in the mandible}

Chronic nonbacterial osteomyelitis is a sterile inflammatory osteitis that most commonly develops in the long bones, but it can occur in any bone. Mandibular lesions are found in $1.5-3 \%$ of disease foci in patients and it is poorly characterized in the maxillofacial surgery literature due to the use of inconsistent terminology. The purpose of this study was to present the clinical experience of chronic nonbacterial multicentric osteomyelitis and a collection of research and information of the disease. This is a retrospective study of 2 cases with mandibular lesions radiographically consistent with osteomyelitis without infection. Medical records were reviewed for history, clinical features, imaging and pathology. The study included 2 patients ( 2 females, age of 17 and 43 years). Both reported mandibular pain and swelling, radiographic finding of multifocal intraosseal inflammatory lesions. Computed tomography scans typically showed expansion of the affected mandible with sclerosis of the medullary space, small foci of poorly defined lytic destruction with lamellated periosteal reaction. Both patients showed a long ineffective antibiotic therapy and recurrent flare-ups of inflammation. After the proper course of treatment (nonsteroid and steroid therapy), a long painless period was reached. Chronic multicentric nonbacterial osteomyelitis has been reported to be uncommon in the 
mandible, but it may be more common with correct diagnosis, typified by recurrent pain and swelling with characteristic pathologic and radiologic features. The current treatment modalities include nonsteroidal anti-inflammatory drugs or steroids.

Keywords: chronic osteomyelitis in the mandible, nonbacterial osteomyelitis, autoinflammatory disease

Danka E, Pintér GT, Keresztúri M, Szabó Gy. [Chronic, nonbacterial, multicentric osteomyelitis in the mandible. A case report and review of the literature]. Orv Hetil. 2018; 159(43): 1761-1766.

(Beérkezett: 2018. március 27.; elfogadva: 2018. május 4.)

\section{Rövidítések}

ANBO $=$ (acute nonbacterial osteitis $)$ akut nem bakteriális osteitis; $\mathrm{CBCT}=$ (cone-beam computed tomography) kúpsugaras $\mathrm{CT} ; \mathrm{CNBO}=($ chronic nonbacterial osteitis $)$ krónikus nem bakteriális osteitio; $\mathrm{CRMO}=($ chronic recurrent multifocal osteomyelitis) krónikus rekurrens multifokális osteomyelitis; CT $=($ computed tomography $)$ számítógépes tomográfia; $\mathrm{MRI}=$ (magnetic resonance imaging) mágnesesrezonancia-vizsgálat; $\mathrm{PPP}=$ palmoplantaris pustulosis; $\mathrm{SAPHO}=$ synovitis, acne, pustulosis, hyperostosis, osteitis

A krónikus, multicentrikus, nem bakteriális eredetú osteomyelitis helyi, steril csontgyulladás, mely gyermekeknél vagy fiatal felnőtteknél (fő́leg nő́knél) fordul elő. Lehet izolált vagy multicentrikus. A leggyakrabban a hosszú csöves csontokban, azok metaphysisében, gyakran a claviculában, sternumban, medencében, esetleg a gerinccsigolyákban fordul elő [1]. Ritkábban más csontokban, így a mandibulában is létrejöhet $[2,3]$.

A betegséget először 1972-ben Giedion és mtsai [4] írták le ,subacute and chronic symmetrical osteomyelitis" néven. Björksten és mtsai [5] nevezték el a kórképet „chronic recurrent multifocal osteomyelitis”-nek (CRMO).

Jellegzetessége a mély, lüktető csontfájdalom, duzzanat, ritkán nem magas láz. A folyamat intermittáló, évekig megkeseríti a betegek életét [6]. Wipff és mtsai [7] 171 beteg sorsát követték. A folyamat 43\%-ban legalább 4 évig tartott. A betegek 71\%-a hosszú évekig kezelést igényelt.

Súlyosabb formában a csontokon kívül egyéb szerveket is érint, társulhat más autoimmun kórképekkel, például a Crohn-betegséggel. Gyermekgyógyászatban ismert az úgynevezett SAPHO-szindróma (synovitis, acne, pustulosis, hyperostosis, osteitis) [8].

A témával kapcsolatos egyik legfontosabb munka 2007-ben Jansson és mtsai [9] tollából került ki, akik retrospektíve 28 év anyagából 89 beteg klinikai, immunológiai és genetikai állapotát mérték fel és hasonlították öszsze. A 89 beteg legtöbbjének a gerincben, a claviculában, a sternumban, a medencében volt az elváltozása (állcsontban: 1,5\%). A betegek $58 \%$-a volt nő; általános állapotuk jó volt, vezető klinikai tünetként a csontfájdalomra panaszkodtak.
A tünetek alapján a betegeket 3 csoportra osztották, és ezt a felosztást másoknak is javasolják.

Az elsó csoportba azok kerültek (89-ből 17-en), akiknél a betegség kezdete 6 hónapnál nem volt régebbi. Ezt a csoportot „acute nonbacterial osteitis”-nek (ANBO) nevezték el.

A második csoportba (89-ból 33) azok kerültek, akiknél a betegség 6 hónapnál régebben kezdődött, remiszszió nem volt, és legalább egy csont érintett volt. Ennek a csoportnak a „chronic nonbacterial osteitis” (CNBO) nevet adták.

A harmadik csoportba (89-ből 39) azok kerültek, akiknél csontlaesio, esetleg palmoplantaris pustulosis (PPP) volt. Itt a hosszabb-rövidebb ideig tartó remissziót recidívák követték. Ennek a csoportnak a „,chronic recurrent multifocal osteomyelitis" (CRMO) nevet adták.

Hisztológiailag nemspecifikus gyulladásos jeleket és csontvelőfibrosist találtak mindhárom csoportban.

Genetikailag eltérést nem észleltek, annak ellenére, hogy bizonyos familiáris komponenst (autoimmun vagy más gyulladásos eredetű betegség) sok esetben találtak.

A diagnózis felállításához „,major és minor” kritériumokat szabtak meg. Az elöbbiekhez 4 tünet tartozik: 1) radiológiailag osteolyticus, szklerotizáló csontlaesio; 2) többszörös csontelváltozás; 3 ) PPP vagy psoriasis; 4) a csontbiopszia steril gyulladást vagy fibrosist, sclerosist mutat.

A minor kritériumok: normálvérkép és jó általános állapot; a CRP és a vérsüllyedés kissé emelkedett; az obszervációs idő több, mint 6 hónap; hyperostosis, más autoimmun betegség a családban előfordult.

Az $A N B O$ diagnózisa akkor állítható fel, ha 2 major vagy 1 major és 3 minor kritérium áll fenn.

A terápiával kapcsolatosan hangsúlyozzák, hogy lehetőleg el kell kerülni a többszörös biopsziát és a hosszan tartó antibiotikus kezelést. A nonszteroid fájdalom- és gyulladáscsökkentők az esetek nagy részében hatásosak. Amennyiben a fájdalom és duzzanat az előző kezelés ellenére még fennáll, szteroidterápiát kell kezdeni, amely sok esetben drámai javulást hoz. Jansson és mtsai szerint [9] a nonbakteriális osteomyelitis ,aluldiagnosztizált" (underdiagnosed) autoimmun betegség, mely akut, krónikus recidiváló vagy krónikus perzisztáló formában jelenik meg. Néhány esetben (gerincbántalmak) próbálkoz- 
tak biszfoszfonátkezeléssel is, de ezek hatása bizonytalan volt [10].

$\mathrm{Az}$ arc-állcsont sebészeti irodalomban az elnevezéssel kapcsolatban bizonyos konfúzió észlelhető: Garré-osteomyelitis, diffúz szklerotizáló osteomyelitis, elsődleges krónikus osteomyelitis, juvenilis alsó állcsonti krónikus osteomyelitis stb. [11-16].

A magyar irodalomban Király és mtsai [17] közöltek egy esetet „Krónikus rekurrens multifokális osteomyelitis" címen. A kórképet egy kilencéves fiúgyermek esetén keresztül mutatják be, akit a jobb térd tájékán észlelt duzzanat, fájdalom miatt kezeltek. Hangsúlyozzák, hogy a betegség felismerésével „számos mütét, hosszas antimikrobás kezelés elkerülhető".

Padwa és mtsai 2016-ban [1] 22, az alsó állcsontra lokalizálódó eset adatai alapján a következőket közölték: mindegyikük mandibulája duzzadt és fájdalmas volt, 45\%-ukban trismus is jelentkezett. Klinikailag és radiológiailag kimutatható volt a multicentrikus intraossealis osteomyelitis. A betegek $54 \%$-ában volt autoimmun vagy autoinflammatiós kórkép.

Radiológiailag az érintett csontrész expanziója, a csontvelő szklerotizációja, kis területeken felritkulás, lamelláris csonthártya-reakció volt látható.

Szövettanilag egyes helyeken párhuzamos osteoid formatiót, máshol kanyargós trabecularis csontszerkezetet, fibroblastokat lehetett kimutatni. A kép bizonyos mértékig hasonló a fibrosus dysplasiához.

Munkánk célja felhívni a figyelmet egy ritkának gondolt, néha az állcsontokat is érintő, hosszan tartó betegségre. Ezt nemcsak a mi tapasztalataink szerint, de a nemzetközi irodalom tanulsága alapján is sokszor félreismerik, helytelen kezelést alkalmaznak. A továbbiakban két beteg történetét ismertetjük, melyek tipikus példái a kezdetben félreismert diagnózisnak és ennek következtében a kezdeti eredménytelen kezelésnek.

\section{Esetismertetés}

Az elsö eset

Első betegünknél (17 éves leány) 14 éves korában fogszabályozás történt. Egy évvel később az alsó fogak gyökércsúcsai alatt $(42,41,31,32,33,34,35,36)$ többgócú, klinikailag és radiológiailag osteomyelitisnek megfelelő elváltozás alakult ki, fájdalmas duzzanattal (1. ábra). Több hónapon át, megszakításokkal antibiotikus kezelésben (Dalacin, Augmentin) részesült, de panaszai állandóan visszatértek. Az antibiotikumok következtében gastrointestinalis problémái jelentkeztek, melyek miatt kezelésben részesült. Allergiás colitisnek megfelelő diagnózist állapítottak meg. Állcsontfájdalmai a duzzanatokkal együtt továbbra is fennálltak, ezért az érintett, bal alsó 6-os (élőnek bizonyuló) fogát trepanálták, de gyökértömést nem végeztek (várva a tünetek megszünését). A betegség kezdetétől számított 3 év múlva irányították a Semmelweis Egyetem (SE) Arc-, Állcsont-, Szájsebészeti és Fogászati Klinikájára. A beteg jó általános állapotban volt, bal oldali, a mandibulára és a mentumra lokalizálódó duzzanata és fájdalmai voltak. Kivizsgálása során laboratóriumi eltérést az enyhén emelkedett sülylyedésen kívül nem észleltek. Az immunológiai vizsgálat szerint az Ellena enzim-1, -3, -4 enyhe pozitivitást mutatott. A családban autoimmun betegség nem fordult elő.

A panorámaröntgen- és a CBCT-felvételek a mentumtájon, a frontfogak alatt, azokkal kissé összefüggő $2 \times 2$ $\mathrm{cm}$-es lyticus-szklerotikus csontdefektust mutattak, a 42 es, 41-es, 31-es, 32-es, 33-as, 34-es, 35-ös és 36-os fog gyökércsúcsai alatt 1-3 mm-es felritkulás volt észlelhető. Ezután a SE Konzerváló Klinikáján az említett fogakat gyökérkezelték, és ezt követően az Állcsontsebészeti Klinikán belső feltárásból a felritkult területeket excochleálták, a gyökértömött fogakat reszekálták. A mütét során

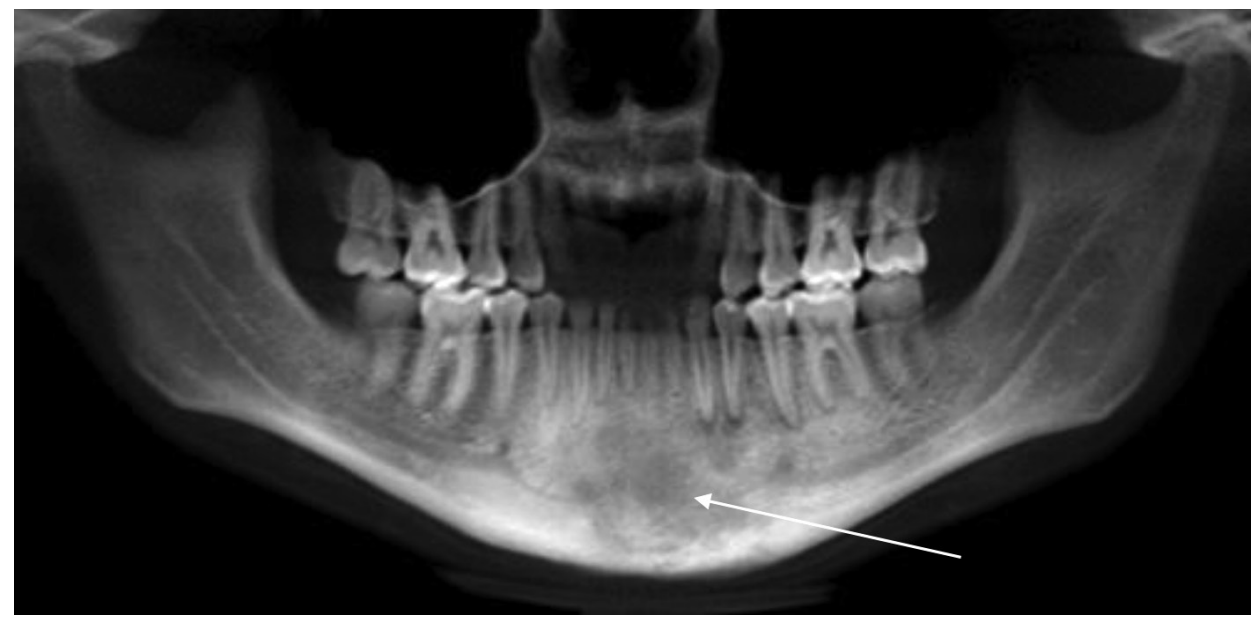

1. ábra

CBCT-felvétel. A nyíllal jelölt területen (mentum) $2 \times 2$ cm-es, a 41 -es, 42 -es, 31-es, 32-es, 34-es, 35-ös és 36-os fog gyökerei alatt kisebb felritkulások láthatók. A mentum területén lévő elváltozásban lyticus és szklerotizáló területek vannak

$\mathrm{CBCT}=$ kúpsugaras $\mathrm{CT}$ 


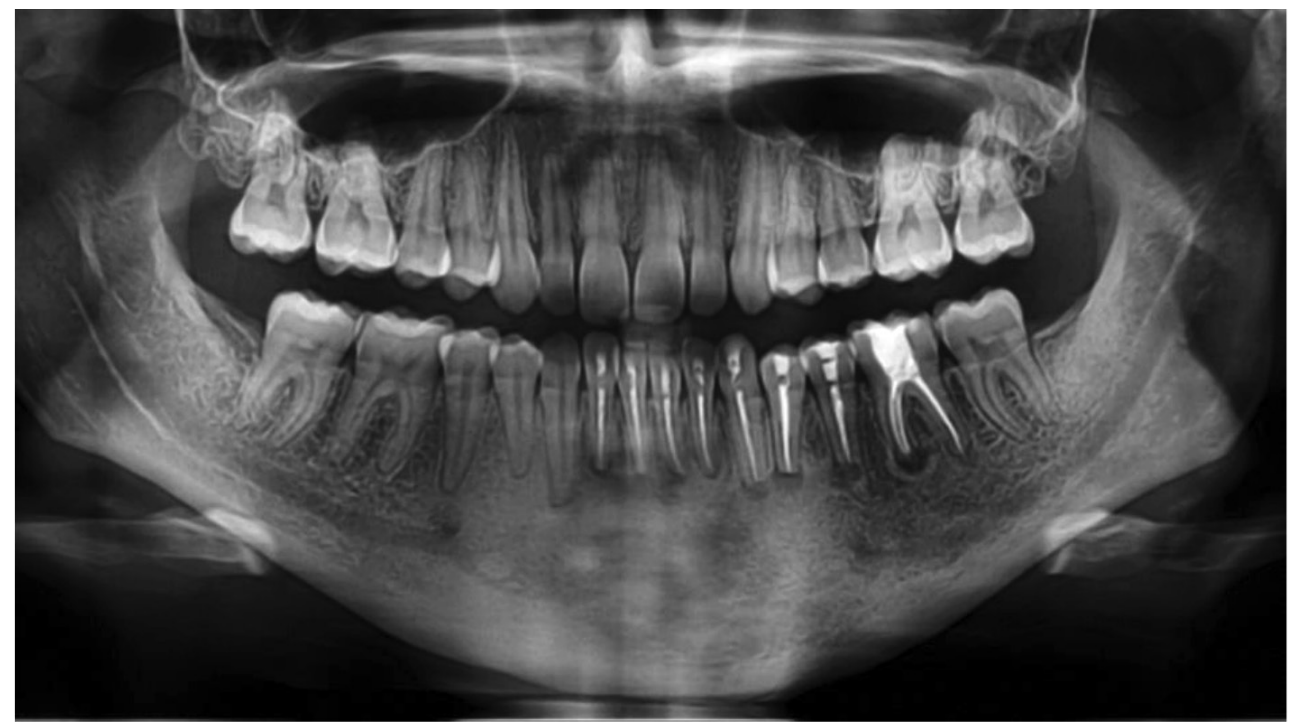

2. ábra

Panorámaröntgen-felvétel. Az 1. ábrán jelzett fogak gyökértömései és a gyökércsúcsok reszekciója utáni állapot látható. A mentum területén dekortikáció történt

gennyes, osteomyelitises területeket nem észleltek. A dekortikált csontra 2 Septopal (Gentamycin)-láncot helyeztek, így a szisztémás antibiotikumos kezelést el lehetett kerülni. A Septopal-láncokat 2 hét múlva távolították el (2. ábra). A mútétet követő egy hónap panaszmentesség után a tünetek újra jelentkeztek, ezért 2017 februárjában szteroidkezelést kezdtek (a nemszteroid gyulladáscsökkentők hatástalanok voltak). A szteroid hatására drámai javulás következett be, néhány napos kezelés után a panaszok megszüntek. Ez a szünet 3 hónapig tartott, de a tünetek megismétlődésekor két-három napos szteroidkezelés újra tünetmentességet eredményezett.

\section{A második eset}

A második beteg szintén nő. Panaszai 37 éves korában kezdődtek: a 46-os foga körül fájdalmat érzett, körülötte duzzanat jött létre. A beteg külföldön, hajón dolgozott, így csak 2 hónap múlva látta fogorvos, aki a jelzett fogat eltávolította. A fájdalom nem szűnt meg, ezért váltakozó antibiotikumkezelésben részesült. CT- és MRI-felvételek készültek, melyek az eltávolított fog helyén többszörös, nem jól definiálható felritkulást és szklerózist állapítottak meg. Biopszia is történt, amely nem bakteriális gyulladást, fibrosist, szklerotikus csontállományt, a szklerotikus trabeculák között idült, gyulladásos sejteket talált. Ezután újból antibiotikus kezelést kezdtek, amely hatástalannak bizonyult, a fájdalom továbbra is fennállt. Az eltelt 6 év alatt több orvos látta, de panaszai nem szűntek, ezért hazajött Magyarországra. A SE Arc-, Állcsont-, Szájsebészeti és Fogászati Klinikáján multicentrikus, nem bakteriális eredetû recidiváló osteomyelitist diagnosztizáltak (3. ábra). A családban autoimmun betegség előfordult. A nonszteroid gyulladáscsökkentők nem hozták meg a kellő hatást, ezután szteroidkezelést kezd- tek, amely szinte azonnal panaszmentességet eredményezett. A beteg újra tud dolgozni, több mint 3 hónapja panaszmentes.

\section{Megbeszélés}

A krónikus multicentrikus, nem bakteriális osteomyelitis az állcsontokban ritkának feltételezett betegség. Jansson és mtsai [9] 89 betegéből 1,5\%-ban voltak érintettek az állcsontok. Monsour és Dalton [3] 4 esetről számol be, Bocchialini és mtsai [2] egy esetet közölnek, viszont Padwa és mtsai [1] 22 beteg sorsát követik.

Wipff és mtsai [7] nagy létszámú feldolgozásában 178 betegnek 458 elváltozása volt; a mandibula érintettségét csak 9 beteg esetében találták, ebból 8 multifokális volt. Továbbá azt észlelték, hogy az unifokális esetek nagy része multifokálissá válik. Csupán 7\%-uk maradt 4 év múlva is egygócú.

Borzutzky és mtsai [18] vizsgálatai szerint azokban a betegekben, akiknek az osteitis mellett autoimmun betegségük is van (arthritis, psoriasis), a lefolyás sokkal agresszívebb, és nagyobb a multifokális tünetek száma.

Baltensperger és mtsai [11] harminc, állcsontokat érintő esetet dolgoztak fel 2004-ben. A betegek megoszlása két fó csoportot mutatott, a 14 év alattiakét és az 50 év felettiekét. A terápia sebészi, antibiotikus és túlnyomásos oxigén volt. A megfigyelési idő alatt (30 év[!]) a 30 betegból 11 került teljes remisszióba, 14 esetben javulás következett be, és 5 esetben a kezelés hatástalan volt. Tapasztalataik alapján új elnevezést javasolnak korai és felnőttkori krónikus osteomyelitis néven.

Az esetek ritkaságát bizonyos fokig megkérdőjelezik a nómenklatúrában lévő különbségek, a diagnosztikus nehézségek, tévedések, a kórkép nem kellő ismerete. A betegek egy részénél ezért a kezelés is, legalább az első idő- 


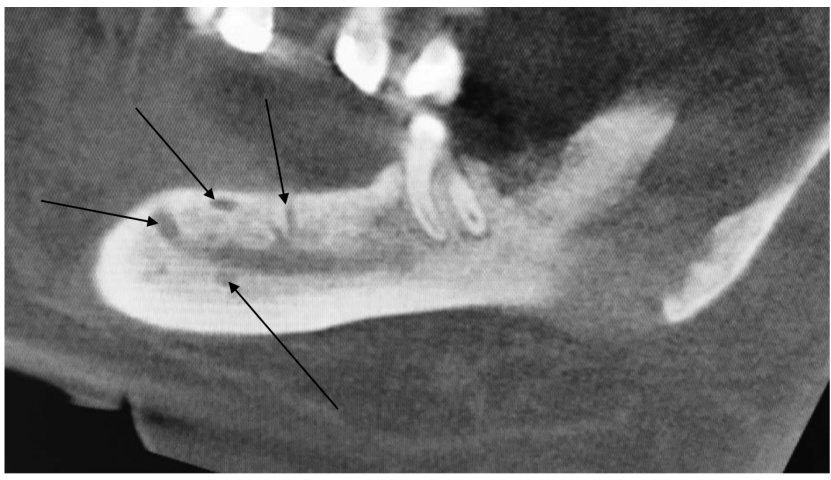

3. ábra

CBCT-felvétel. A mandibulában a canalis mandibularis körül (a nyilakkal jelölt területeken) csontfelritkulások láthatók

$\mathrm{CBCT}=$ kúpsugaras $\mathrm{CT}$

szakban, félresikerülhet: a gyulladásos tünetek miatt a kezdeti terápia a legtöbbször a hosszú távú antibiotikus kezelés, többfajta gyógyszer alkalmazása (azok minden mellékhatásával) és a többszöri biopszia.

A betegség okával kapcsolatosan csak feltételezések vannak. Hummell és mtsai [19] alacsony virulenciájú mycoplasmafertőzésre gondolnak. King és mtsai [20], valamint mások [21] genetikus okot feltételeznek. Eredete bizonyos fokig összefügghet autoimmun betegségekkel. Az érintettek családjának 40\%-ában találtak ilyen elváltozást [9].

A betegség kezelésében mindenekelőtt a diagnózis szükséges, ami a klinikai tünetek (csontfájdalom, duzzanat, jó általános állapot, a süllyedés enyhe emelkedése) és a radiológiai jelek (csontvelőödéma, többszörös csontfelritkulás, szklerózis) alapján lehetséges [22-24]. A csontbiopszia nem mutat bakteriális fertőzést, hypocellularis fibroblastos stroma, szklerotikus csontgerendák láthatók.

Differenciáldiagnózisként a bakteriális osteomyelitis, osteosarcoma, Langerhans-histiocytosis jöhet számításba [1].

\section{Kezelés}

Elsősorban a nemszteroid gyulladáscsökkentók javasoltak. Ezek az esetek több mint felében hatásosak. Ha a fájdalom és a duzzanat nem változik, akkor szteroidkezelés indikált, amely a legtöbb esetben gyors javulást eredményez. Javasolják még a recidívák elkerülésére, hogy hosszabb ideig, fenntartható kezelésként alacsony dózisban alkalmazzák a szteroidot. Az antibiotikus kezelés általában hatástalan, vagy csak minimális javulást eredményez. Mútétet (excochleatio, dekortikáció) csak ritkán javasolnak [1].

Az első esetben a dekortikációt azért végezték, mert csaknem minden gyökércsúcs alatt felritkulás volt. A Septopal-láncot pedig a felülfertőzés elkerülése miatt alkalmazták. Felmerült később az is, hogy szteroidkezeléssel talán a mútét is elkerülhető lett volna.

\section{Következtetés}

A krónikus, nem bakteriális, multicentrikus osteomyelitis a mandibulában ritkán előforduló, hosszan tartó betegség. Sokszor más jellegú autoimmun betegséggel áll kapcsolatban. Sem az oka, sem a patofiziológiája nem tisztázott teljesen. A diagnózis a klinikai, radiológiai és szövettani vizsgálatok alapján állítható fel. Kezelésében a nemszteroid vagy a szteroid gyulladáscsökkentők jönnek számításba.

Anyagi támogatás: A közlemény megírása anyagi támogatásban nem részesült.

Szerzôi munkamegosztás: D. E.: Betegkezelés. P. G. T.: Képalkotó diagnosztika. K. M.: Irodalomkutatás. Sz. Gy.: Témavezetés. A cikk végleges változatát valamennyi szerző elolvasta és jóváhagyta.

Érdekeltségek: A szerzőknek nincsenek érdekeltségeik.

\section{Irodalom}

[1] Padwa BL, Dentino K, Robson CD, et al. Pediatric chronic nonbacterial osteomyelitis of the jaw: clinical, radiographic, and histopathologic features. J Oral Maxillofac Surg. 2016; 74: 23932402.

[2] Bocchialini G, Ferrari L, Rossini M, et al. Chronic nonbacterial osteomyelitis involving the mandible: a case report. Int J Surg Case Rep. 2017; 37: 149-153.

[3] Monsour PA, Dalton JB. Chronic recurrent multifocal osteomyelitis involving the mandible: case reports and review of the literature. Dentomaxillofac Radiol. 2010; 39: 184-190.

[4] Giedion A, Holthusen W, Masel LF, et al. Subacute and chronic symmetrical osteomyelitis. Ann Radiol. 1972; 15: 329-342.

[5] Björkstén B, Gustavson KH, Eriksson B, et al. Chronic recurrent multifocal osteomyelitis and pustulosis palmoplantaris. J Pediatr. 1978; 93: 227-231.

[6] Suei Y, Tanimoto K, Taguchi A, et al. Chronic recurrent multifocal osteomyelitis involving the mandible. Oral Surg Oral Med Oral Pathol. 1994; 78: 156-162.

[7] Wipff J, Costantino F, Lemelle I, et al. A large national cohort of French patients with chronic recurrent multifocal osteitis. Arthritis Rheumatol. 2015; 67: 1128-1137.

[8] Marx R. Diffuse sclerosing osteomyelitis of the mandible: its characteristics and possible relationship to synovitis, acne, pustulosis, hyperostosis, osteitis (SAPHO) syndrome. J Oral Maxillofac Surg. 1996; 54: 1199-1200.

[9] Jansson A, Renner ED, Ramser J, et al. Classification of nonbacterial osteitis: Retrospective study of clinical, immunological and genetic aspects in 89 patients. Rheumatology 2007; 46: 154-160.

[10] Compeyrot-Lacassagne S, Rosenberg AM, Babyn P, et al. Pamidronate treatment of chronic noninfectious inflammatory lesions of the mandible in children. J Rheumatol. 2007; 34: 15851589.

[11] Baltensperger M, Grätz K, Bruder E, et al. Is primary chronic osteomyelitis a uniform disease? Proposal of a classification based on a retrospective analysis of patients treated in the past 30 years. J Craniomaxillofac Surg. 2004; 32: 43-50.

[12] Renapurkar S, Pasternack MS, Nielsen GP, et al. Juvenile mandibular chronic osteomyelitis. Role of surgical debridement and antibiotics. J Oral Maxillofac Surg. 2016; 74: 1368-1382. 
[13] Heggie AA, Shand JM, Aldred MJ, et al. Juvenile mandibular chronic osteomyelitis. A distinct clinical entity. Int J Oral Maxillofac Surg. 2003; 32: 459-467.

[14] Girschick H, Zimmer C, Klaus G, et al. Chronic recurrent multifocal osteomyelitis: what is it and how should it be treated? Nat Clin Pract Rheumatol. 2007; 3: 733-738.

[15] Eyrich GK, Baltensperger MM, Bruder E, et al. Primary chronic osteomyelitis in childhood and adolescence: a retrospective analysis of 11 cases and review of the literature. J Oral Maxillofac Surg. 2003; 61: 561-570.

[16] Eyrich GK, Langenegger T, Bruder E, et al. Diffuse chronic sclerosing osteomyelitis and the synovitis, acne, pustolosis, hyperostosis, osteitis (SAPHO) syndrome in two sisters. Int J Oral Maxillofac Surg. 2000; 29: 49-53.

[17] Király B, Feith S, Barta M, et al. Chronic recurrent multifocal osteomyelitis. [Krónikus rekurrens multifokális osteomyelitis.] Orv Hetil. 2003; 144: 2531-2533. [Hungarian]

[18] Borzutzky A, Stern S, Reiff A, et al. Pediatric chronic nonbacterial osteomyelitis. Pediatrics 2012; 130: el190-el197.

[19] Hummell DS, Anderson SJ, Wright PF, et al. Chronic recurrent multifocal osteomyelitis: are mycoplasmas involed? $\mathrm{N}$ Engl J Med. 1987; 317: 510-511.
[20] King SM, Laxer RM, Manson D, et al. Chronic recurrent multifocal osteomyelitis: a noninfectious inflammatory process. Pediatr Infect Dis J. 1987; 6: 907-911.

[21] Hofmann SR, Roesen-Wolff A, Hahn G, et al. Update: Cytokine dysregulation in chronic nonbacterial osteomyelitis $(\mathrm{CNO})$. Int $\mathrm{J}$ Rheumatol. 2012; 2012: 310206.

[22] Khanna G, Sato TS, Ferguson P. Imaging of chronic recurrent multifocal osteomyelitis. Radiographics 2009; 29: 1159-1177.

[23] Jurik AG, Egund N. MRI in chronic recurrent multifocal osteomyelitis. Skeletal Radiol. 1997; 26: 230-238.

[24] Sabbioni G, Del Piccolo N, Gualdrini G. Chronic recurrent multifocal and aspecific osteomyelitis: a case report. Musculoskelet Surg. $2010 ; 94: 45-47$.

(Szabó György dr., Budapest, Mária u. 52., 1085 e-mail: szabogy@dent.semmelweis-univ.hu)

\section{NOTA \\ Új fejlesztés az egészségügyben dolgozók, tanulók részére!}

A magyar nyelvứ szakirodalmi keresőszolgáltatás

\section{Mi a NOTA? \\ Napivizit Orvosi Tudástár Alkalmazás}

Mit tud a NOTA portál?

Megkönnyíti a magyar nyelvú szakirodalmi források keresését.

Eszköztöl függetlenül, aká állva is használható. okostelefonról, a betegágy mellett

\section{Miben kereshet a NOTA-val?}

Az Akadémiai Kiadó folyóirataiban: Orvosi Hetilap, Magyar Sebészet, Mentálhigiéné és Pszichoszomatika.

\section{Más kiadók magyar nyelvú}

szakfolyóirataiban: pl. Lege Artis Medicinae, Hypertonia és Nephrologia, Ideggyógyászati Szemle.

A hatályos szakmai irányelvekben.

Magyar nyelvű kérdésekre adott angol nyelvű találatokban, a PubMeden.

\section{nota.hu}

Amennyiben további információra lenne szüksége, keressen minket elérhetőségeinken:
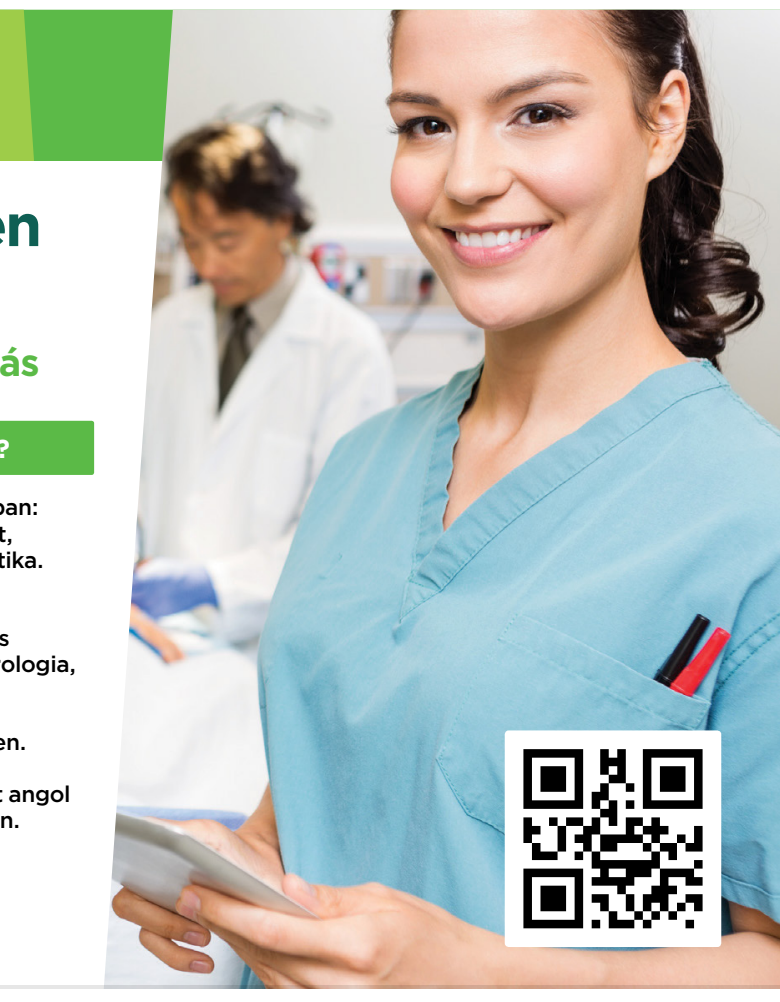

Akadémiai Kiadó

A Wolters Kluwer Csoport tagja

1117 Budapest, Prielle Kornélia u. 21-35. / Telefon: (1) 464-8246

www.akademiai.hu / www.akademiai.com
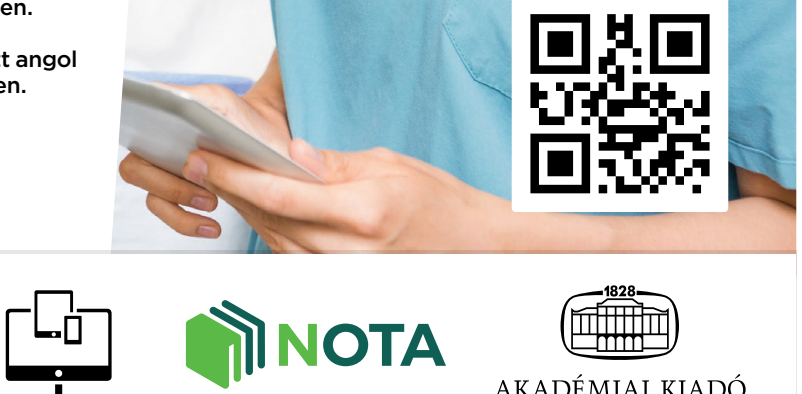

AKADÉMIAI KIADÓ

A cikk a Creative Commons Attribution-NonCommercial 4.0 International License (https://creativecommons.org/licenses/by-nc/4.0) feltételei szerint publikált Open Access közlemény, melynek szellemében a cikk nem kereskedelmi célból bármilyen médiumban szabadon felhasználható, megosztható és újraközölhető, feltéve, hogy az eredeti szerző és a közlés helye, illetve a CC License linkje és az esetlegesen végrehajtott módosítások feltüntetésre kerülnek. 